\title{
STOOL ANALYSIS OF 3000 CHILDREN IN BANGLADESH
}

by

\author{
N. Muarzam ${ }^{1}$ and M.G.Muazzam ${ }^{2}$
}

Kun\% (1960) first published a report of stool examination of 300 school children near Dhaka showing a high prevalence of intestinal protozoa and helninths. Muttalib et al. (1976) published a report on the prevalence of intestinal parasites in the rural children of Bangladesh. Muazzam et al. (1968) published a similar report from Rajshahi Medical College based on 664 stool examinations of which 564 were children and 100 were infants. There are several publications showing the incidence of intestinal parasites in this area but these included all the age groups (Muazzam and All. 1961: Muazzam.1962a 1962 b: Khan and Muazzam, 1962: Muazzam. 1963: Muazzam, 1964: Khan and Muazzam. 1965: Khan and Muazzam. 1966: Muazzam. 1966 and Muaziam et al. 1968). The reports of Kun\% and Muttalib seem too high and their number of subjects is very small for giving a national incidence. Besides. the pattern of findings of stool analysis varies in different age groups due to different living conditions. diet. environment etc. So a report on a large number of children is necessary to get a more reliable incidence rate.

\section{Materials and Methods}

3000 stool specimens of children aged above one year to twelve years were mostly examined in the Ibn Sina Laboratory. Dhaka during the period 1984-1987. Among them $1854(61.8 \%)$ were male and $1146(38.2 \%)$ were females making a ratio of $1.6: 1$.

Routine saline and iodine preparations were examined as soon as possible and lloatation technique (Maplestone. 1934) was done if necessary. Test for reducing substance in the stool was also done in some cases if requested by the clintcians. The diagnosis of acule bacillary dysentery was based on both physical and microscopic findings, characterlsed by the presence of a large number of epithelial cells. pus cells, red cells and macrophages.

\section{Results and Discussion}

Table 1 shows the microscopic findings and Table 2 shows the total number of pathological findings including those found in combination. Table 3 and 4 show the age and sex distributions of ascarfasis and trichuriasis.

\section{Microscopic findings}

1. Indigestion - In $1200(40 \%)$ children. the only pathological finding was indigestion (Table 1) characterised by the presence of significant number of vegetable cells. fat globules.. fatty acid crystals or soaps, starch granules and muscle fibres either singly or it

1. Assoc. Prol. Microbtology, Dhaka Meclical College. Dhaka.

2. Direckur, Jbn Sina Lib., Dhaka. 
combination. Thus a very large number of children complaint of G 1 tract trouble due to simple indigestion. In 495 cases. indigestion was found in combination with other pathological findings, making a tolal of $1695(56.50 \%)$ Table 2.

2. Helminths - Only helminthic infections were found among $742(24.73 \%)$ subjects while helminthic infections in 168 cases in combination with other pathological findings were found making a total of $910(30.33 \%)$. The incidence of different types of helminliss varied wiclely (Table 1 and 2).

(a) Ascariasis - Round worm Inlection was the commonest intestinal helminth in children in our study. There were $569(18.98 \%)$ specimen showing the presence of ova of Ascaris lumbricoldes alone (Table 1 ) but in 16 more cases ascaris ova was found along with other significant pathological findings like acute bacillary dysentery and giardiasis. Thus the actual number of ascariasis is $585(19.50 \%)$ (Table 2). Kun\% (1960) reported $66.0 \%$ ascariasis among village children of a primary school near Dhaka. Hassan (1986) reports $60.48 \%$ ascariasis among 946 school children of Dhaka city. Muazzam et al. (1968) reported $25.60 \%$ ascariasis in Rajshahi Medical Collge. It seems there are many silent cases of ascariasis among children and only those will somewhat serious complaints go for treatment to the clinictans. So to obtain true incidence. study should include slum area, modernised area and areas with or without sanitary lacility. Besides the patients coming to the consultants belong to richer group with modern living conditions.

The incidence of ascariasis in the series between male and female children had a ratio of $1.67: 1$ which is comparable to the $1.6: 1$ sex ratio of 1968 (Muazzam et al.) series. Age distribution of ascariasis shows that higher incidence of ascariasis was found between 1 to 2 years to the 8 th year and the incidence declined gradually from the 9th year. Hassan (1986) however reported higher prevalence in the 5 to 9 years group.

(b) Trichuriasis - Whip worm infection alone accounts for only $127(4,23 \%)$ subjects (Table 1) which is comparable to $4.06 \%$ reported in the 1968 series (Muazram et al. 1968). But the actual number of positive specimens for whip worm (Trichuris trichiura) ora was $263(8.76 \%$ ) as in 136 cases (Table 2) these were present in combination wilh ascariasis, hook-worm infection. giardiasis, bacillary and amoebic dysenteries. Hassan (1986) however reports a very high percentage or trichuriasis $(60.72 \%)$ in his paper. The infection in this series was higher in 3 to 9 years group and the sex ratio is 1.94:1 for male and lemale chlldren.

(c) Hook worm infection - Ova of hook-worm were found in only $28(0.93 \%)$ specimens (Table 1 ) which is much lower than $47.0 \%$ reported by Kun $(1960)$ and $16.4 \%$ reported by Muazzan et al. (1986). in Rajshahi. With 5 more cases in combination the total number is however $33(1.11 \%)$ Table 2 . The reason of such low incidence may be the same as -iggested for ascariasis. However, in a previous study in Dhaka (Muariam and All. 1961) hook wom ova were lound in $23.9 \%$ of 2412 stool specimens and $14.5 \%$ among 820 ( tse: admitted in Rajshahi Medical College (Khan and Muazzam, 1965). But these two r. pon i included patients of all age group. Hassan (1986) reported no hook-wonm ova in 
his study of school children in Dhaka. He used only cellopliane thick smear techniqu and loatation method was not employed. Thus in this case also no reliable rate of nation: prevalence is known.

(c) Enterobius vermicularis - Thread worm infection was found in only $5(0,17 \%)$ subjects (Table 1) but the actual number was $9(0.3 \%)$ (Table 2). As stool examination is not enough to exclude thread worm infection, the actual prevalence remains unknown. Scotch-tape method should be adopted to find out true prevalence rate of enteroblasis Hassan (1986) reported $0.76 \%$ prevalence in school children of Dhaka.

(d) Trematodes - Only $10(0.33 \%)$ cases of Hymenolepis nana were found in this series (Table 1) though actual number was $12(0.4 \%)$ (Table 2). Hassan (1986) reported $0.57 \%$ whereas Muazyam et al. (1968) reported $0.90 \%$ in Rajshahi. So all these figures are comparable. Only one case of Fsciolopsts buski was found $(0.03 \%)$ (Table 1). which is lower than $0.2 \%$ reported by Muakam and Ali. 1961 in their series of all age groups

3. Proto\%oa :- (a) Amoeblasis - Entamoeba histolytica infection was detected in 42 subjects (Table 1) but the total number was $45(1.50 \%)$ with three more cases of combined infection. This is lower than $2.26 \%$ reporled by Muaram et al. (1986) in Rajshahi and much lower than $37.0 \%$ reporled by Kunz (1960). The tolal number of all strains of amoeba as single infection was $82(2.73 \%)$ and the total prevalence of all stains including those non-pathogenic strains lound in combination is 317 (Table 2) making a rate of $12.06 \%$ (362) which is still lower than that of Kun\% (1960),

(b) Giardiasis - There were $230(7.67 \%)$ cases of giardiasis (Table 1) as single infection but the actual prevalence was $8.67 \%(260)$ in the series (Table 2). This is comparable to $9.37 \%$ reported by Muaziam et al. (1986) though lower than $18.0 \%$ reported by Kun\% (1960).

(c) Trichomoniasis - There were 4 cases of single infection and 2 cases of combined infection making a total of $6(0,2 \%)$ in this serles (Table 2). This figure is lower than $1.66 \%$ reported by $\mathrm{K} 1 \mathrm{~m} \%$ (1960) but much lower than $7.68 \%$ reported by Muazzam el al. (1968). Kun\% examined only preserved specimen carried to USA and it is very difficult to identify trichomona species unless they are alive and moving. Hassan (1986) did not
repport on trichomona infection.

4. Blastocystis homonis- The single infection of Bl. homonis was $98(3.27 \%)$ though the actual number lound was $220(7.33 \%)$ in the series (Table $1 \& 2$ ). Kun\% and Hassan clid
not report any blastocystis infection.

5 . Yeasts - Yeast inlection was found in $49(1.63 \%)$ subjects though actual number was 84 $(2.80 \%)$ with the combined inlections (Table 1 \& 2).

6. Bacillary dysentery- There were $148(4.93 \%)$ cases of acute bactllary dysentery based on microscopic lindings (Table 1). There were $30(1.0 \%)$ cases of non-specific collitis characterised by patches of muctus with epthelial cells. pus cells and lew red cells and occasional macrophages but these are not spread all over the field. Since bacteriological study was not done. these are lebelled as non-speciftc colitis.

$417(13.90 \%)$ spectmens showed no significant pathological findings (Table 1). Thus 
$86.10 \%$ specimens of laeces showed some abnormal findings under microscope. Total prevalence of intestinal helminths was $30.33 \%(910)$ and total pathogenic proto\%oa were $10.33 \%$ (311) making a prevalence rate of $40.66 \%$ for all intestinal parasiles. Thts figure is much lower than $66.09 \%$ (helminths $46.97 \%+$ Path. proto\%oa $19.12 \%$ ) reported in the 1968 series and $80 \%$ reported among rural children by Multalib et al. (176). The lower incidence than that of 1968 series may be due to type of children reported to the specialists in Dhaka to whom poorer class rarely go tor treatment.

\section{Conclusion}

From the above findings it is clear that the prevalence of intestinal parasites vary widely in different parts of Bangladesh and in different socio-economic as well as urban and rural population groups.

Stool examination is one of the common investigations in a routine diagnostic laboratory. Clinicians usually advise stool examination for all patients having complatnts referable to the gastro-intestinal tract. Stool examination traditionally means exclusion of the presence of larva, ova. protozoa and cysts of the intestinal parasites and amoebic or bacillry dysentery. But there are important findings besides these which may help the clinicians to treat their patients. Presence of fat globules. fatty acids as crystals or soaps. presence of occult blood, presence or absence of bile. presence of excess of vegitable cells, starch granules and muscle fibres, presence of yeasts and Blastocystis homonis and the presence of reducing substance in the stool are of significance for the clinicians. So the clinicians and the clinical pathologists should have close contact and the clinicians must understand the significance of all the microscopic findings in the stool examination report. Thus the detailed examination of stool or faeces should be termed stool analysis instead of stool examination.

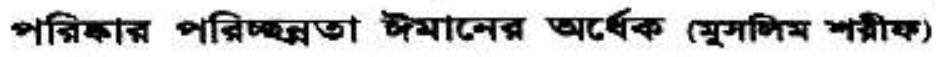

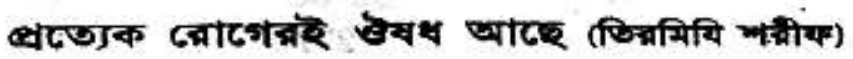


Table 1. Showing the microscoping findings of 3000 stool specimens of children aged up to 12 years.

A. Intestinal parasites: Single infection Microscopiv Findings
Number Percent positive
B. Other Findings :

Microscopic: Findings
Number l'ercent positive

\section{Helminths}

1. Ova, Ascarts $\mathrm{L}$.

2. Ova, Trichuris lo

3. Ova. Hook worm

4. Ova Enl, vern

5. Esge. H. nana

6. Elge. F. buskl

7. Larva, sil, slercorahis Total

\section{Protozoa :}

8. Ent. histolytica

9. Non-l'ath. amoebae

10 Glarclia lamblla

11. Tricho. hominis Total Grand Total

569

127

28

05

10

01

02

742
18.98

4.23

0.93

0.17

0.33

0.03

0.07

24.74
1. Indigestion

2. Acute Bacillary clysentery

3. Non. spectift colitted

4. Bl. hominis

5. Yeasts

6. No Abnormal finding Total
1200

148

30

98

49

417

1942
40.00

4.93

1.00

3.27

1.63

13.90

64.73

Table 2. Showing total number of pathological findings among 3000 children in Dhaka. Findings :

\begin{tabular}{lccrr}
\hline A. Helminths : & $\begin{array}{c}\text { No. as single } \\
\text { infection }\end{array}$ & $\begin{array}{c}\text { No. in } \\
\text { combination }\end{array}$ & $\begin{array}{c}\text { Total } \\
\text { number }\end{array}$ & $\begin{array}{c}\text { True } \\
\text { percentage }\end{array}$ \\
\hline 1. Ascaris L. & 569 & 16 & 585 & 19.50 \\
2. Tri. trichura & 127 & 136 & 263 & 8.76 \\
3. Hook worm & 28 & 05 & 33 & 1.11 \\
4. Ent. verm. & 05 & 04 & 09 & 0.30 \\
5. Str. sterco & 02 & 05 & 07 & 0.23 \\
6. Hym, nana & 10 & 02 & 12 & 0.40 \\
7. F. buski & 01 & 00 & 01 & 0.03 \\
Tolal & 742 & 168 & 910 & 30.33 \\
B. Protozoa : & & & & \\
1. Ent. hisiolytica & 42 & 03 & 45 & 1.50 \\
2. Non-Path. amoebae & 40 & 277 & 317 & 10.56 \\
3. G. Lamblla & 230 & 30 & 260 & 8.67 \\
4. Tr. hominis & 04 & 02 & 06 & 0.20 \\
Total & 316 & 312 & 628 & 20.93 \\
C. Other Findings : & & & & \\
1. Bl. hominis & 98 & 122 & 220 & 7.33 \\
2. Yeasis & 49 & 35 & 1695 & 2.80 \\
3. Indigestion & 1200 & 495 & & 56.50 \\
\hline
\end{tabular}


Table 3. Showing sex and age distribution of Ascaris lumbricoides infection among 3000 children in Bangladesh.

\begin{tabular}{cccc}
\hline Age groups & $\begin{array}{c}\text { Number } \\
\text { Male }\end{array}$ & $\begin{array}{c}\text { Number } \\
\text { Femal }\end{array}$ & Total \\
\hline Above 1 to 2 yrs & 44 & 20 & 64 \\
" 2 to 3 yrs & 43 & 18 & 61 \\
" 3 to $4 "$ & 42 & 21 & 63 \\
" 4 to $5 "$ & 42 & 34 & 76 \\
" 5 to $6 "$ & 41 & 24 & 65 \\
$" 6$ to $7 "$ & 39 & 31 & 70 \\
$" 7$ to 8 " & 35 & 22 & 57 \\
" 8 to $9 "$ & 28 & 16 & 44 \\
$" 9$ to $10 "$ & 20 & 14 & 34 \\
$" 10$ to 11 " & 18 & 10 & 28 \\
11 to 12 " & 14 & 09 & 23 \\
Total & 366 & 219 & 585 \\
\hline
\end{tabular}

Sex ratio of male $:$ Fernale $=1.67: 1$

Table 4. Age and Sex distribution of Trichuris trichiura infection among Children.

\begin{tabular}{|c|c|c|c|c|c|}
\hline \multicolumn{2}{|c|}{ Age groups } & Male & Female & \multicolumn{2}{|l|}{ Total } \\
\hline Mor & han 1 - 2 yrs. & 8 & 7 & 15 & \\
\hline & $=\quad 2-3^{\prime \prime}$ & 13 & 8 & 21 & \\
\hline " & $3-4 "$ & 22 & $\cdot 10$ & 32 & \\
\hline ; & $4-5 "$ & 20 & 16 & 36 & \\
\hline$"$ & $" 5-6 "$ & 33 & 10 & 43 & : \\
\hline " & $" 6-7 "$ & 18 & 10 & 28 & ? \\
\hline " & $7-8 \quad$ & 20 & $12^{\circ}$ & 22 & \\
\hline$"$ & $" \quad 8-9^{\prime \prime}$ & 16 & 9 & 25 & \\
\hline$"$ & $" 9-10 "$ & 8 & 7 & 15 & \\
\hline$"$ & $" 10-11 "$ & 5 & 3 & 8 & \\
\hline , & $" 11-12 "$ & 4 & 4 & 8 & \\
\hline & & 167 & 96 & 263 & \\
\hline
\end{tabular}

Sex ratio- Male : Female $=1.94: 1$ 


\section{References}

1. Hassan, A. (1986) : Praslte Prevalence among the school children of Dhaka clity. personal communication.

2. Khan. A. K. and Muazzam. M. G. (1962) : Diarrhoeal Diseases - I (Amoebic dysentery). Medical Bulletin. Rajshahi, $1: 21-30$

3. Khan A. K. and Muazzam. M.G. (1965) : Hook-worm Infection in East Pakistan and its Treatment. Pak J Med Res, vol-4, no.-2, Pp 184-189

4. Khan, A.K. and Muazzam, M.G. (1966) : Diarrhoeal Diseases II (Intestinal Flagellates). Medical Bulletin, Rajshahi, 3: 12-15

5. Kunz. R.E. (1960) : Intestinal Protozoa and Helminths in School Children of Dhaka. Am. J. Trop. Med. \& Hyg., 9:168-172

6. Maplestone; P. A. (1934) : The Laboratory Dlagnosis and Treatment of Intestinal Helminths Infectlon Found in India, Bengal Govt. Press, p 24

7. Muazzam, M.G. and All, M.T. (1961) : Intestinal Parasites in East Pakiștan, J. Pak. Med. Assoc., 11:185-194

8. Muazzam, M.G. (1962a) : Ascariasis in East Pakistan. The Medicus, Karachi. 24:160-166

9. Muazzam, M.G. (1962b) : Hook-worm Infection in East Pakistan, Healer, Chittagong, 1:24

10. Muazzam, M.G. (1963) : Amoebiasis in East Pakistan. J. PAK. Med. Asșoc. (East zone), Khulna brance, vol-1, No-2, Pp $I=6$

11. Muazzam. M.G. (1964) : Intestinal Flagellates. Ibld, vol-2, No-1, Pp 1-6

12. Muazzam. M.G. (1966) : Pathology. Laboratory Dlagnosis and Prevention of Intestinal Helminths. The Medicus, Karachl, 33:68-73

13. Muazzam, M.G., Khan, M.K. and Istám, M.N. (1968) : Incidence of Intestinal Parasites among Children of East Paklstan. The Medicus, Karachl, $35: 210-215$

14. Muttalib. M.A. et al. (1976) : Prevention of Intestinal Parasites in Rural Children of Bangladesh. Bang. Med. J., volume 5. 